\title{
Karyotype of the Chinese soft-shelled turtle, Pelodiscus sinensis, from Japan and Taiwan, with chromosomal data for Dogania subplana
}

\author{
HIROYUKI SATO ${ }^{1}$ AND HIDETOSHI OTA ${ }^{2 *}$ \\ ${ }^{1}$ Graduate School of Science and Engineering, University of the Ryukyus, Nishihara, \\ Okinawa, 903-0213 JAPAN \\ ${ }^{2}$ Tropical Biosphere Research Center, University of the Ryukyus, Nishihara, Okinawa, 903- \\ 0213 JAPAN
}

\begin{abstract}
Abst[ract: The male and female karyotypes were examined for 10 specimens of the Chinese soft-shelled turtle, Pelodiscus sinensis, from the main islands of Japan and Taiwan by the bone marrow air-dry technique. One specimen of Dogania subplana was also examined karyologically. Although both $P$. sinensis and $D$. subplana had $2 \mathrm{n}=66$ chromosomes, they showed an interspecific variation in chromosome morphology. No karyotypical differences were evident between the Japanese and Taiwanese samples of $P$. sinensis, or within either of them. Comparisons of the present results with previously reported trionychine karyotypes indicate that there are some interspecific and intraspecific variations in centromeric positions of several macrochromosome pairs in this subfamily.
\end{abstract}

Key words: Turtle; Chromosomes; Japan; Taiwan; Karyotype

\section{INTRODUCTION}

The Chinese soft-shelled turtle, Pelodiscus sinensis (Wiegmann, 1835), is widely distributed in the eastern part of the Eurasian continent and adjacent islands, i.e., an area from eastern Russia to northern Vietnam, including the main islands of Japan, Taiwan, Hong Kong, and Macao (type locality) (Iverson, 1992). Based on an allozyme study, Sato and Ota (1999) reported genetic differentiations between populations of this species from the main islands

\footnotetext{
${ }^{*}$ Corresponding author. Tel: +81-98-895-8937; Fax: +81-98-895-8966.

E-mail address: ota@sci.u-ryukyu.ac.jp (H. Ota)
}

of Japan, and Taiwan and Hong Kong. Oguma $(1936,1937)$, in the initial description of the karyotype of $P$. sinensis, reported that male and female turtles from southern Japan (probably Kyushu) had $2 n=64$ chromosomes in a spermatogonium and 63 in an oogonium, respectively. He argued that the difference in diploid number between male and female cells represents the ZO type of sex chromosome heteromorphism. Later, Suzuki (1950) also reported 64 and 63 chromosomes, respectively, for male and female soft-shelled turtles from Korea. More recently, however, Bickham et al. (1983) claimed that all trionychid specimens examined by them, including a male $P$. sinensis from an unknown locality, had $2 n=66$ chrom 
somes without any heteromorphism. They, while ignoring Suzuki's (1950) report, assumed that the difference between their results and the results of Oguma's $(1936,1937)$ investigation was derived from miscounting of chromosomes by the latter. Rong and Li (1984) also reported the diploid chromosome number in $P$. sinensis from continental China to be 66. However, no authors subsequent to Oguma $(1936,1937)$ and Suzuki (1950) examined Japanese and Korean populations of $P$. sinensis karyologically.

Considering that both Oguma $(1936,1937)$ and Suzuki (1950) adopted the classical paraffin sectioning, a method which sometimes makes it difficult to discriminate small chromosome elements correctly (Gorman, 1973), the claim by Bickham et al. (1983), who employed a more advanced cell culturing with leukocyte cells for chromosome preparation, sounds plausible. However, there is another possibility that the differences between results in those works actually reflect the differentiation between the Japanese-Korean and other populations as was demonstrated by allozyme analysis (Sato and Ota, 1999).

Thus, we re-examined the karyotype of $P$. sinensis from Japan and Taiwan by the bone marrow air-dry method, because this method yields better resolution of metaphase cells than the gonadal sectioning (Sharma, 1980). A specimen of the Malayan soft-shelled turtle, Dogania subplana, one of the closest relatives of $P$. sinensis (see Meylan, 1987), was also examined.

\section{MATERIALS AND METHODS}

A total of 10 hatchlings of $P$. sinensis and one hatchling of $D$. subplana were used. Of these specimens, five, four, and one $P$. sinensis were from Amamioshima Island of the Ryukyu Archipelago, Taiwan, and Minamidaitojima Island, respectively, whereas the sample of $D$. subplana was purchased from a pet dealer and its locality was thus unknown. Samples of $P$. sinensis from Amamioshima and Minamidaitojima are regarded as representing populations from the mainislands of Japan and Taiwan, respectively, since current populations on those two Islands of the Ryukyus are known to have been derived from recent artificial introductions from these main islands (Sato et al., 1997; Sato and Ota, 1999). Voucher specimens are deposited in the herpetological collection of the Department of Zoology, Kyoto University (KUZ), as KUZ 48712-48716 (specimens from Amamioshima), 48717 (Minamidaitoujima), 48735, 48737-48739 (Taiwan), and 47851 (D. subplana).

All specimens were injected with colchicine solution $(0.1 \mathrm{mg} / \mathrm{ml})$ into their body cavities at $0.05 \mathrm{mg} / \mathrm{g}$ body weight. They were euthanized with pentobarbital solution about $12 \mathrm{hr}$ after the colchicine injection. Bone marrow cells, extracted from a femur of each specimen, were subjected to hypotonic treatment in $\mathrm{KCl}$ solution $(0.05 \mathrm{~mol} / \mathrm{l})$ for $40 \mathrm{~min}$, and then were rinsed and fixed in Carnois solution (glacial acetic acid:methanol, 1:3). Chromosome preparations made by the air-dry method were soaked in 3\% Giemsa solution for $30 \mathrm{~min}$ and then were observed microscopically and photographed. The karyotype was determined for each individual on the basis of at least five well-spread metaphase cells. Terminology for chromosomal descriptions follows Green and Sessions (1991).

Specimens karyotyped were sexed by histological examination of gonadal sections. Gonads, removed from each specimen along with an adjacent portion of kidney, were infiltrated and embedded in paraffin, and then were sectioned at $10 \mu \mathrm{m}$ and stained with hematoxylin and eosin solutions. Sexual identification follows the criteria used by Yntema and Mrosovsky (1980).

\section{RESULTS}

Microscopical observations of gonadal sections explicitly showed sexual features for each specimen. In male gonads, no cortex was observed, and cells in the medullary region were organized into seminiferous tubules (Fig. 1A). In female gonads, on the other hand, a relatively thick cortex covered the ventral surface 


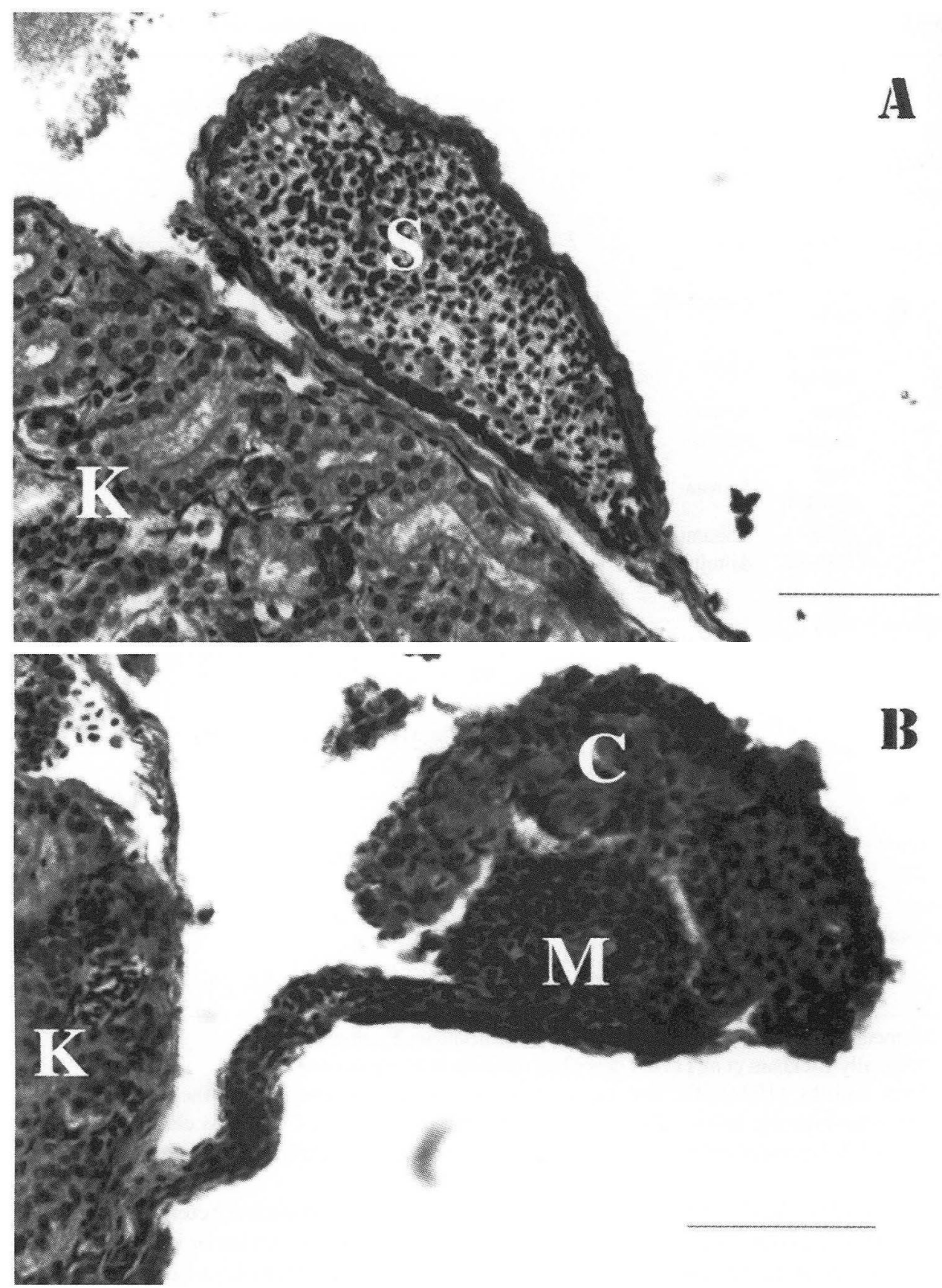

FIG. 1. Histological sections of gonads from male (A: KUZ 48737) and female (B: KUZ 48739) hatchlings of Pelodiscus sinensis. K, kidney; S, cells organized into seminiferous tubules; C, cortex; and M, unorganized medulla. Horizontai scale bars represent $50 \mu \mathrm{m}$. 
TABLE 1. Diploid chromosome numbers and morphology of macrochromosomes (Nos. 1-8) in trionychine turtles reported so far. Populations on Amamioshima and Minamidaitojima are known to have been derived from artificial introductions from the main islands of Japan and Taiwan, respectively (see text).

\begin{tabular}{|c|c|c|c|c|c|c|c|c|c|c|}
\hline & Tissues & & $\begin{array}{l}\text { Sample size } \\
\text { (male/ }\end{array}$ & Diploid & Morpholog & yy of & chromoso & ome pa & airs $1-8^{*}$ & \\
\hline Species & used & Locality & & number & 123 & 4 & $5 \quad 6$ & 7 & 8 & Sources \\
\hline \multirow[t]{7}{*}{$\begin{array}{l}\text { Pelodiscus } \\
\text { sinensis }\end{array}$} & gonads & Japan & $?$ & $\begin{array}{l}64 / 63 \\
(\mathrm{M} / \mathrm{F})\end{array}$ & --- & - & -- & - & - & $\begin{array}{c}\text { Oguma } \\
(1936,1937)\end{array}$ \\
\hline & gonads & Korea & $?$ & $\begin{array}{l}64 / 63 \\
(\mathrm{M} / \mathrm{F})\end{array}$ & --- & - & -- & - & - & $\begin{array}{l}\text { Suzuki } \\
(1950)\end{array}$ \\
\hline & $\begin{array}{l}\text { leukocyte } \\
\text { cells }\end{array}$ & unknown & $1(1 /-)$ & 66 & $\mathrm{M}, \mathrm{M}, \mathrm{SM}$ & $\mathrm{T}^{* *}$, & $\mathrm{T}^{* *}, \mathrm{ST}$, & $\mathrm{M}$, & M & $\begin{array}{c}\text { Bickham et al. } \\
\text { (1983) }\end{array}$ \\
\hline & $\begin{array}{l}\text { bone } \\
\text { marrow }\end{array}$ & China & $?$ & 66 & $\mathrm{M}, \mathrm{M}, \mathrm{SM}$, & $S M, S$ & $\mathrm{SM}, \mathrm{T}, \mathrm{S}$ & $\mathrm{SM}^{* * *}$ &, $\mathrm{SM}^{* * *}$ & $\begin{array}{l}\text { Rong and Li } \\
\text { (1984) }\end{array}$ \\
\hline & $\begin{array}{l}\text { bone } \\
\text { marrow }\end{array}$ & $\begin{array}{l}\text { Amami- } \\
\text { oshima }\end{array}$ & $5(3 / 2)$ & 66 & $\mathrm{M}, \mathrm{M}, \mathrm{SM}$, & ST, & ST, ST, & SM, & SM & This study \\
\hline & $\begin{array}{l}\text { bone } \\
\text { marrow }\end{array}$ & Taiwan & $4(2 / 2)$ & 66 & $\mathrm{M}, \mathrm{M}, \mathrm{SM}$, & $\mathrm{ST}$ & ST, ST, & SM, & SM & This study \\
\hline & $\begin{array}{l}\text { bone } \\
\text { marrow }\end{array}$ & $\begin{array}{l}\text { Minami- } \\
\text { daitojima }\end{array}$ & $1(1 /-)$ & 66 & $\mathrm{M}, \mathrm{M}, \mathrm{SM}$ & $\mathrm{ST}$, & ST, ST, & SM, & SM & This study \\
\hline \multirow[t]{2}{*}{$\begin{array}{l}\text { Apalone } \\
\text { spiniferus }\end{array}$} & $\begin{array}{l}\text { leukocyte } \\
\text { cells }\end{array}$ & & $3(-/ 3)$ & 66 & $\mathrm{M}, \mathrm{M}, \mathrm{SM}$ & $\mathrm{T}^{* *}$, & $\mathrm{T}^{* *}, \mathrm{ST}$, & $\mathrm{M}$ & M & $\begin{array}{c}\text { Bickham et al. } \\
\text { (1983) }\end{array}$ \\
\hline & $\begin{array}{l}\text { blood and } \\
\text { gonads }\end{array}$ & & $3(2 / 1)$ & 66 & --- & - & -- & - & - & $\begin{array}{l}\text { Stock } \\
(1972)\end{array}$ \\
\hline A. ferox & $\begin{array}{l}\text { leukocyte } \\
\text { cells }\end{array}$ & & $1(1 /-)$ & 66 & $\mathrm{M}, \mathrm{M}, \mathrm{SM}$ & $\mathrm{T}^{* *}$, & $\mathrm{T}^{* *}, \mathrm{ST}$, & $\mathrm{M}$, & M & $\begin{array}{c}\text { Bickham et al. } \\
\text { (1983) }\end{array}$ \\
\hline A. muticus & $\begin{array}{l}\text { blood and } \\
\text { gonads }\end{array}$ & & $7(4 / 3)$ & 66 & --- & - & -- & - & - & $\begin{array}{l}\text { Stock } \\
\text { (1972) }\end{array}$ \\
\hline $\begin{array}{l}\text { Amyda carti- } \\
\text { lagineus }\end{array}$ & - & & $?$ & 66 & --- & - & -- & - & - & $\begin{array}{c}\text { Gorman } \\
\text { (1973) }\end{array}$ \\
\hline \multirow[t]{2}{*}{$\begin{array}{l}\text { Dogania } \\
\text { subplana }\end{array}$} & $\begin{array}{l}\text { blood and } \\
\text { gonads }\end{array}$ & & $2(2 /-)$ & 66 & --- & - & -- & - & - & $\begin{array}{l}\text { Stock } \\
(1972)\end{array}$ \\
\hline & $\begin{array}{l}\text { bone } \\
\text { marrow }\end{array}$ & & $1(-/ 1)$ & 66 & $\mathrm{M}, \mathrm{M}, \mathrm{SM}$, & $\mathrm{ST}$, & ST, ST, & $\mathrm{T}$, & $\mathrm{T}$ & This study \\
\hline
\end{tabular}

*: M, metacentric; SM, submetacentric; ST, subtelocentric; T, telocentric.

**: Originally Bickham et al. (1983) described telocentric as acrocentric.

***: Rong and Li (1984) did not explicitly describe the morphology of the seventh and eighth macrochromosome pairs. However, based on the photograph of arranged chromosomes given in that paper, we tentatively considered these pairs to be submetacentric.

of the gonadal body containing visible oocytes, and the medullary region contained unorganized medulla (Fig. 1B). By these criteria, three specimens from Amamioshima, two from Taiwan and the one from Minamidaitojima were identified as males, and the remainder, including the representative of $D$. subplana, were identified as females (Table 1).
No sex chromosome heteromorphisms, either in chromosome number or in morphology, were evident in any metaphase cells examined at the Giemsa level. We consider macrochromosomes to be so large in size that centromeric positions can be unambiguously determined even in spreads of mediocre quality. The five specimens of $P$. sinensis from Amamioshima had a 

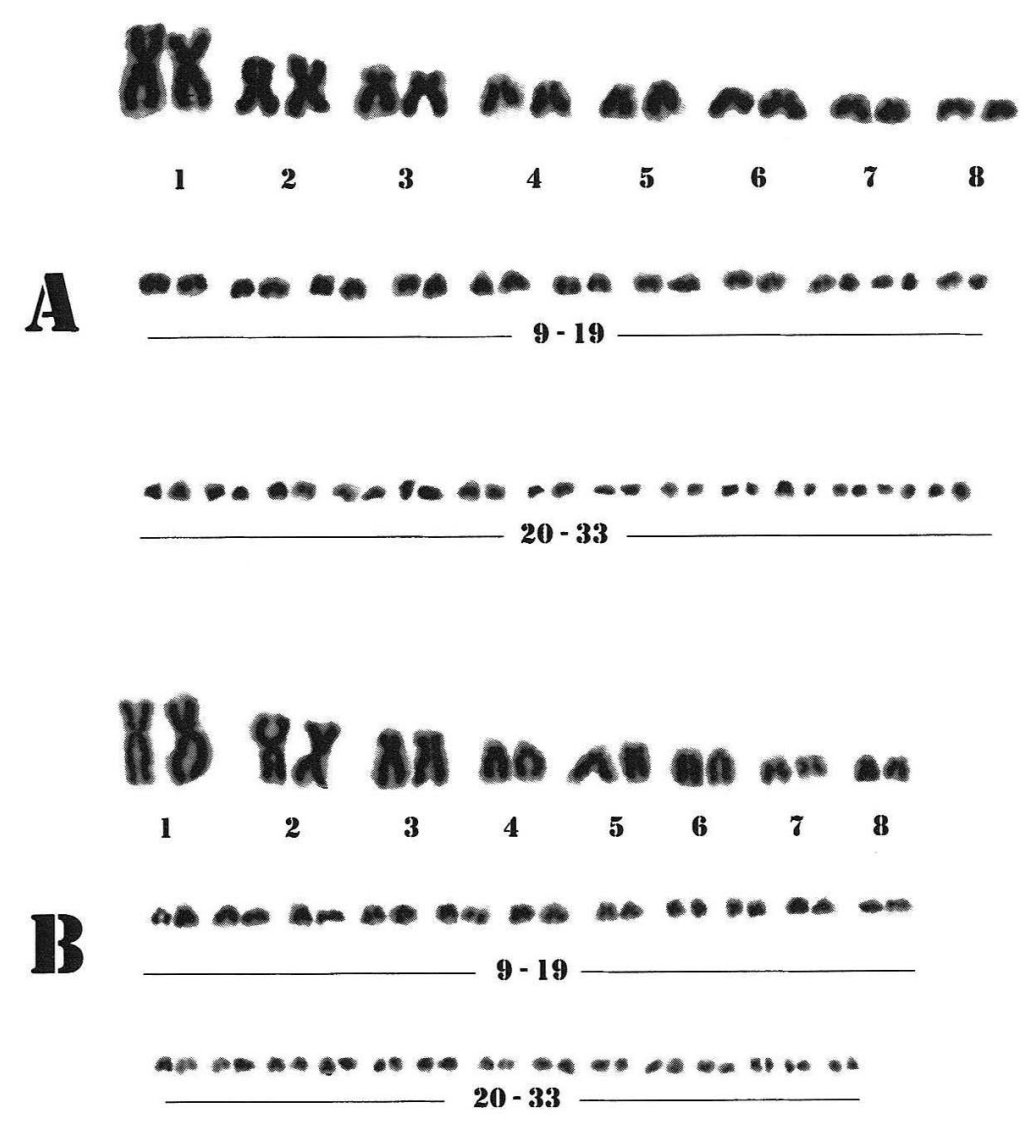

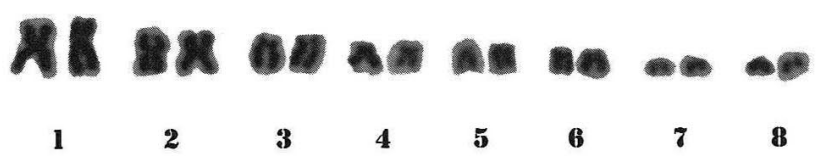

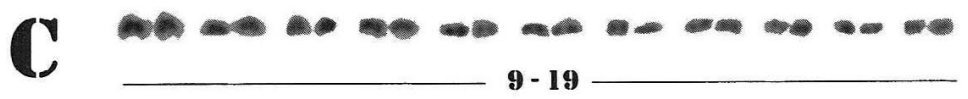

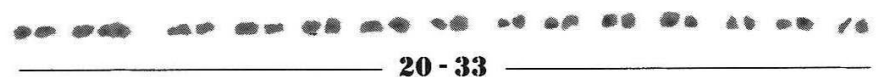

FIG. 2. Karyotypes of trionychine turtles obtained from the bone marrow cells. A, female Pelodiscus sinensis from Amamioshima (KUZ 48716; 2n=66). B, male P. sinensis from Taiwan (KUZ 48737; 2n=66). C, female Dogania subplana (KUZ 47851; 2n=66). Scale-bar represents $10 \mu \mathrm{m}$. 
karyotype consisting of $2 n=66$ chromosomes. Of these, the largest eight pairs were macrochromosomes, of which the first and second pairs were metacentric, the third submetacentric, pairs 4-6 subtelocentric, and pairs 7 and 8 submetacentric. The remaining 25 pairs were microchromosomes with centromeres most likely being located terminally (Fig. 2A). Karyotypes of the Minamidaitojima male, and the four specimens from Taiwan, appeared to be identical with the karyotype of the Amamioshima sample described above (Fig. 2B). The karyotype of the female $D$. subplana, though also being composed of $2 \mathrm{n}=66$ chromosomes, differed from the $P$. sinensis karyotype in macrochromosome morphology: in the D. subplana karyotype, pairs 7 and 8 were telocentric instead of submetacentric (Fig. 2C).

\section{DISCUSSION}

All specimens examined in the present study, including both male and female representatives for populations from the main islands of Japan, had $2 n=66$, an apparently homologous karyotype. Such a chromosomal arrangement, while being consistent with those of $P$. sinensis of unknown locality and from continental China reported by Bickham et al. (1983) and Rong and $\mathrm{Li}$ (1984), substantially differs from those reported by Oguma $(1936,1937)$ and Suzuki (1950) for samples from the main islands of Japan and Korea, respectively (Table 1). Considering the technical disadvantage of the gonadal sectioning methods (Gorman, 1973; Sharma, 1980: see above), it is highly likely that such differences did not reflect actual intraspecific variation, but were due to miscounting of chromosomes by the previous authors.

It is generally considered that chromosome morphology in the cryptodiran turtles is quite invariable, with most confamilial and consubfamilial species possessing invariable karyotypes (e.g., Bickham and Carr, 1983; Stock, 1972). With respect to the Trionychinae, Bickham et al. (1983) reported that three spe- cies of two genera examined by them $(P$. sinensis, Apalone spiniferus, and $A$. ferox) had almost identical karyotypes (Table 1). They thus predicted an extremely low chromosomal variability in the subfamily. Our results, however, partially negate this prediction, because they show that: (1) the karyotypes of $P$. sinensis and D. subplana differ from each other in centromeric positions in macrochromosome pairs 7 and 8 (Figs. 2A, B, and C); (2) the karyotypes of $P$. sinensis and D. subplana obtained in the present study differ from those of other Trionychinae species (Apalone spiniferus, and $A$. ferox) reported by Bickham et al. (1983) in morphology of macrochromosome pairs 4, 5, 7, and 8 (Table 1); and (3) the karyotype of $P$. sinensis from the present study differs from conspecific karyotypes reported by Bickham et al. (1983) and Rong and $\mathrm{Li}$ (1984) in centromeric position in macrochromosome pairs 4, 5, 6, 7, and 8 (Table 1). Of these, (1) and (2) indicate the presence of karyotypic variation at an intergeneric level in this subfamily, whereas (3) strongly suggests the presence of an intraspecific chromosomal variation in $P$. sinensis. Thus, we suspect that in the subfamily Trionychinae, the morphology of macrochromosomes is more variable than was expected by Bickham et al. (1983), although the diploid, macrochromosome, and microchromosome numbers are highly conservative. Further extensive surveys of karyotypes in other trionychine species are needed to verify this prediction.

Very few authors have studied chelonian karyotypes by the bone marrow air-dry method (Kamezaki, 1989). In the present study, however, we successfully obtained many hematopoietic metaphase cells by this method. Even so, preliminary attempts at karyotyping using the same method for adult $P$. sinensis $(\mathrm{n}=4$, CL larger than $150 \mathrm{~mm}$ ) yielded no metaphase cells at all (Ota, unpublished data). It is thus probable that adult turtles tend to reduce active cells in the bone marrow, and that in turtles the bone marrow air-dry method is most effective for juveniles. 


\section{ACKNOWLEDGMENTS}

We thank Mr. T. Kanmura and Dr. Y. Yasukawa for provision of materials studied here, Dr. E. Hirose for technical advice for gonadal sections, Miss. S. Yamashiro for helping with the laboratory work, and Prof. E. Zhao, Dr. S.-L. Chen, and Prof. K. Adler for literature. This research was partially supported by a grant from the Association for the Preservation of Aquatic Resources, Japan (to H. Ota).

\section{Literature Cited}

BICKHAM, J. W. AND J. L. CARR. 1983. Taxonomy and phylogeny of the higher categories of cryptodiran turtles based on a cladistic analysis of chromosomal data. Copeia 1983(4): 918-932.

BICKHAM, J. W., J. J. BULL, AND J. M. LEGLER. 1983. Karyotypes and evolutionary relationships of trionychoid turtles. Cytologia 48(2): 177-183.

Gorman, G. C. 1973. The chromosomes of the Reptlila, a cytotaxonomic interpretation. p. 349-424. In: A. B. Chiarelli and E. Capanna (eds.), Cytotaxonomy and Vertebrate Evolution. Academic Press, New York.

GREEN, D. M. AND S. K. SESSIONS 1991. Nomenclature for chromosomes. p. 431-432. In: D. M. Green and S. K. Sessions (eds.), Amphibian Cytogenetics and Evolution Academic Press, San Diego.

IVERSON, J. B. 1992. A Revised Checklist with Distribution Maps of the Turtles of the World. Privately printed, Richimond, Indiana. $363 \mathrm{p}$.

KAMEZAKI, N. 1989. Karyotype of the loggerhead turtle, Caretta caretta, from Japan. Zool. Sci. 6(2): 421-422.
MEYLAN, P. A. 1987. The phylogenetic relationships of soft-shelled turtles (family Trionychidae). Bull. Am. Mus. Nat. Hist. 186(1): 1-101.

OGUMA, K. 1936. Sexual difference of chromosomes in the soft-shelled turtle. Jpn. J. Genet. 12: 59-61.

OGUMA, K. 1937. Studies on sauropsid chromosomes. III. The chromosomes of the soft-shelled turtle, Amyda japonica (Temminck and Schleg.), as additional proof of female heterogamety in the Reptilia. J. Genet. 34(2): 247-264.

RONG, S.-B. AND X.-W. LI. 1984. The karyotype of Amyda sinense. Zool. Res. 5 (suppl. 3): 29-31. (in Chinese with English summary)

SATO, H. AND H. OTA. 1999. False biogeographical pattern derived from artificial animal transportations: A case of the soft-shelled turtle, Pelodiscus sinensis, in the Ryukyu Archipelago, Japan. p. 317-334. In: H. Ota (eds.), Tropical Island Herpetofuna: Origin, Current Diversity, and Conservation. Elsevier, Amsterdam.

SATO, H., T. YoshINO, AND H. OTA. 1997. Origin and distribution of the Chinese soft-shelled turtle, Pelodiscus sinensis (Reptilia: Tesudines), in islands of Okinawa Prefecture, Japan. Biol. Mag. Okinawa (35): 19-26. (In Japanese with English abstract)

SHARMA, A. K. 1980. Chromosome Techniques: Theory and Practice. Third Edition. Butter Worths, London. $711 \mathrm{p}$.

STOCK, A. D. 1972. Karyological relationships in turtles (Reptilia: Chelonia). Can. J. Genet. Cytol. 15(4): 859-868.

SUZUKI, K. 1950. Studies on the chromosomes of Korean soft-shelled turtle (Amyda maackii, Brandt) with special reference to the sex chromosomes. Jpn. J. Genet. 25(5/6): 222. (in Japanese)

YNTEMA, C. L. AND N. Mrosovsky. 1980. Sexual differentiation in hatchling loggerheads (Caretta caretta) incubated at different controlled temperatures. Herpetologica 36(1): 33-36. 